\title{
Dr Joseph Edward Rall
}

\author{
Jan Wolff and P Reed Larsen
}

The scientific community, especially in the field of modern endocrinology, has lost one of its most influential members - Dr Joseph Edward (Ed) Rall, who died on 28 February 2008, aged 88 years.

Dr Rall's training spanned internal medicine at Northwestern University, Chicago, IL, an Endocrinology Fellowship at the Mayo Clinic, Rochester, MN, and a PhD from the University of Minnesota on radiodine kinetics. In 1950, he moved to Memorial Sloan-Kettering Cancer Center, New York, NY, where he was a key member of Dr Rulon Rawson's group investigating strategies for the safe use of radioactive iodine in the treatment of thyroid cancer. He also began productive collaborations with Dr Jacob (Jack) Robbins on the biochemistry of radioiodine-labeled thyroid proteins. While in New York, he met Dr Robert Conard of Brookhaven National Laboratories, which eventually led to his important role in studies of radioiodine fallout from nuclearweapon tests in the Marshall Islands and after reactor accidents.

In 1955, Dr Rall was invited by the NIH to organize the Clinical Endocrinology Branch (CEB) of the National Institute of Arthritis and Metabolic Diseases in Bethesda, MD. His vision was to recruit a multidisciplinary group of individuals who would focus their collaborative efforts on the study of thyroid physiology and disease. The group included Hans Cahnmann (organic chemist), Harold Edelhoch (physical chemist), Charles Lewallen (an expert on radioiodine kinetics), Jack Robbins (a thyroid-cancer specialist and protein chemist) and Jan Wolff (a physician and scientist with expertise in iodide transport). The CEB provided a seminal environment in which many of the principles underlying thyroid physiology were developed, including the landmark work by Rall and Robbins, published in 1960, which elucidated the biological importance of free (as opposed to total) thyroid hormone in the circulation.
His vision

was to recruit

a multi-

disciplinary

group of

individuals

who would

focus their

collaborative

efforts on the

study of thyroid

physiology

and disease

J Wolff is Chief

of the Endocrine

Biochemistry Section

of the Laboratory

of Biochemistry

and Genetics in the

National Institute

of Diabetes and

Digestive and Kidney

Disease, Bethesda,

MD, USA. PR Larsen

is the Editor-in-Chief

of Nature Clinical

Practice Endocrinology

\& Metabolism.

\section{Competing interests}

The authors declared no

competing interests.

www.nature.com/clinicalpractice doi:10.1038/ncpendmet0871
Progress made in the CEB validated Dr Rall's prescient concept that advances in biomedical science were most likely to occur when the insights and quantitative discipline of the basic scientist were combined with the pathophysiological contributions of the sophisticated clinician. For many young physician trainees - PR Larsen included - a fellowship at the CEB was viewed as the essential starting point for a biomedical career. In later years, the CEB's remit expanded to include such topics as diabetes, growth-hormone disorders and gonadal dysfunction, but always with an emphasis on understanding the fundamental basis of the disorder. Many visiting international scientists were attracted to this center and provided a broad intellectual perspective. Such interactions led to a near-permanent association between the CEB and the Naples laboratory of Nino Salvatore.

In the 1970s and 1980s, Dr Rall was Scientific Director of the National Institute of Diabetes and Digestive and Kidney Diseases and, later, Deputy Director of Intramural Research at the $\mathrm{NIH}$. In these roles, he shielded the intramural community from the excesses of directed research and visualized the $\mathrm{NIH}$ as a promoter of basic biomedical studies. He had the remarkable capacity to listen with genuine interest to scientific and research matters, even proposals that seemed highly speculative. Though he provided incisive criticism, he encouraged colleagues to develop their ideas; Nobel laureates Barry Blumberg, Chris Anfinsen, Marty Rodbell and Marshall Nirenberg were among the many scientists who thrived in this fertile environment.

Ed Rall's many colleagues will also fondly remember the parties at his home, trips to the Farm, the soccer games, the (not entirely successful) attempts to play trio sonatas, and the encouragement to spend time in foreign laboratories. He befriended many of us, and was a true Renaissance Man who will be deeply missed. 